\title{
Mobile Learning Quality of Education and Increase in Student Discipline
}

\author{
Abdel Rahman Ibrahim1, Nik Mohd Rahimi Nik Yusoff', Mohd Yusri Kamarudin ${ }^{3}$ \\ ${ }^{1}$ Permata Insan Centre, Islamic Science University of Malaysia, Nilai, Malaysa \\ ${ }^{2}$ Faculty of Education, National University of Malaysia, Bangi, Malaysia \\ ${ }^{3}$ Ministry of Education, Putrajaya, Malaysia \\ Email: abdelrahman@usim.edu.my, nik@ukm.edu.my,yusriqanun@yahoo.com
}

Received 16 February 2016; accepted 8 April 2016; published 11 April 2016

Copyright (C) 2016 by authors and Scientific Research Publishing Inc.

This work is licensed under the Creative Commons Attribution International License (CC BY).

http://creativecommons.org/licenses/by/4.0/

(c) (i) Open Access

\begin{abstract}
Mobile learning is the most popular platform of learning and education nowadays. One of these strategic projects is "Kelas Maya" (virtual-class system) in Terengganu state in Malaysia. Six primary schools there are presently using the module. This case study chose Sekolah Kebangsaan Paya Bunga from schools in Terengganu for this case study. The objectives of this study are to verify students' attitude about e-learning and the real impact of virtual classroom system at the level of students' academic achievement as well as to determine the change achieved by this system on the habits of school students. Eighty students studied in SK Paya Bonga (thirty-one boys and forty nine girls) via the Kelas Maya system. After collecting information about student academic achievement and attendance to school and discipline in general, the researcher made a comparison between student's achievement before and after using the virtual class. The comparison shows an increase in student academic achievement and also student attendance to the school and their general discipline, which is related to the school ranking on the state level and country level. According to the findings, the researcher recommends that the government continue to apply this system for this level of student, because of the many benefits academic and behavioural.
\end{abstract}

\section{Keywords}

Mobile Learning, Virtual Class, Student Discipline

\section{Introduction}

The Education Apps Store (EAS) Samsung UK and the Educational App Store (EAS) are working together to transform the way students learn, as well as help teachers to achieve more positive learning outcomes. This is 
one example of the innovation in teaching and learning nowadays, and this innovation makes it imperative for educators to achieve education objectives, as in the Internet age and technology age, educators should be ready for these innovations. They should not find themselves outside the technological system and teaching modern science by old means.

Many theories of learning have been advanced over the 2500 years between Confucius and the present day, but almost all have been predicated on the assumption that learning occurs in a school classroom, mediated by a trained teacher. A few educational thinkers have developed theory-based accounts of learning outside the classroom, including Argyris \& Schön (1996), Illich (1970), and Tiedeman \& Knowles (1979), but none have placed the mobility of learners and learning as the focus of enquiry. However, with the emergence of the Internet in the early 1990s, the education community has witnessed the appearance of software products labelled Virtual Learning Environments (VLEs) that aim to support learning and teaching activities across the Internet. Then began the development of learning technology in all aspects, involving use of the computer and the Internet within the classroom. After that came the evolution of e-books and tablet devices and the continued evolution of technology itself through use in the field of education, especially higher education.

A desire to keep abreast of developments in the field of education and the adoption of modern teaching aids made the Ahtmad system of e-learning and virtual classrooms in primary schools in the state of Terengganu the first experiment of its kind in Malaysia. The researcher has investigated student and teacher attitudes toward using virtual classrooms and e-learning. The study examines students' grades before and after the application of this system and as well as their commitment to school time before and after the application of this system.

In this research, the researcher is trying to answer research questions which are attached below.

What is Kelas Maya's effect on the students' learning achievement?

What are students' reactions to Kelas Maya?

What is Kelas Maya's effect on student's discipline?

\section{Defining and Implementing Virtual Class Room (Kelas Maya)}

Virtual class room one of the recent education tools, it's fellow the modern technology and new strategic for learning, many of researcher are support this way for teaching and learning, Apple's iPad has attracted a lot of attention since its release in 2010, and one area in which it has been adopted is the education sector (Henderson \& Yeow, 2012). Virtual classes provide an elegant solution to the extensibility problem how to easily extend a data abstraction with both new representations and new operations (Ernst, Ostermann, \& Cook, 2006).

Virtual classrooms and mobile learning using students time as full time for education and learning and mac easy for them to discus with teachers about their class, not only inside a class room. Al-Khalifa (2006) perceives learning management system as a platform for students to complete task quickly, upload various types of files into its environment, enabling users to access the information at anytime and anywhere, while also allowing users to communicate with other students in the course and the tutor electronically (Trayek, Sariah, \& Hassan, 2013). One part of a learning management system is that mobile learning can change student lives, not just in education but also technology. Students use new styles of learning such as virtual class and mobile learning. E-books can be transported at the speed of light anywhere around the world instantly. Saving an eBook on disk or CD after compressing it into a ZIP file can allow for the bundling of information into a mass of electrons being beamed across the Internet. There is no need for more heavy text books (Dietzel, 2002).

The Internet revolution, mobile learning, virtual class allow students to explore more and more in their academic level or upper than it, nowadays students can discus with their friends by discussion groups and even social media with chatting and video conference. This increases students' knowledge and thinking among themselves and increases the credibility of the information. It has the greatest impact on the academic level of students.

\section{Theoretical Framework}

The new learning or new education style contribute many benefits for the new wings of education operation, and the main reason is the emergence of the Internet and technology such as electronic learning and mobile learning and virtual class room, which save time and avoid some big problems. Therefore, the majority of students accepted mobile learning and virtual class rooms as they make the education environment more flexible and easy. There are many types of learning activities outside the classroom. For example, students may visit museums to 
observe some artefacts or collect some specimens in the field trip (Liu, Liao, \& Pratt, 2009). Therefore, mobile learning technology has great support in the learning environment in schools, including primary schools, which we are going to investigate the impact of this technology in this schools, Perceived usefulness is defined as the degree to which a person believes that using a virtual class room and mobile learning would improve the learning progress. In addition, the diversity of information and sources increases the knowledge of the students and the variety of methods and teaching aids in the effectiveness of both education and fun.

This study has focused on the effect of using mobile learning, going back to study of the theory by Davis (1985) as originally derived from Fishbein and Ajzen (1975) which focuses on the justification action for the using or non-use of technology in general. This includes user-perceived benefit or perceived ease of use of technology and its ability to provide the required level of learning, per the Figure 1.

Figure 2 below shows the conceptual model used in this study. This figure shows the independent variables and the dependent variables that represent (DOS) and Academic Achievement (AA) and the independent variables are Comfortable Education (CE) and Usability and Easier for Carry (EFC) Discipline of students.

This study has two dependent variables, Discipline of Students (DOS) in the school and Academic Achievement (AA). The impact of virtual classrooms and Mobile learning on these two variables through three independent variables are the Comfortable Education (CE) and Usability and Easier for Carry (EFC) through a program of virtual classrooms and mobile education.

The educator and those interested in the education and learning should think in the time of technology, what technology gives to the educational process, and how to convince students that technology is the best way to teach, Mobile learning technologies offer teachers and students a more flexible approach to learning. Computer labs are great, but do students use technology in the classroom, in the school garden, in the study hall, in the gym, or on field trips? With mobile learning devices, you can do all this, and more (Nordin, Hamzah, Yunus, \& Embi, 2010; Wylie, 2009). This has a profound effect on the ways in which children learn. They are more engaged in learning when using the latest technological gadgets, because it is what they are most used to interacting with. Students do not just want mobile learning, they need it.

Also, convenient and flexible education offers students and teachers come relief from stress and allows other educational behaviour. These behaviours may well drive learning away from short term priorities, and mobile learning is convenient and flexible (it can be accessed anywhere, at any time) and so offers a powerful opportunity to introduce learning "on demand"-at the exact moment it is required (West \& Paine, 2012). In addition, e-books are easy to carry from one place to another compared to conventional books. PDAs have a large screen (for a portable device) that makes reading easy. They also combine several computing and communication tools in one device. Text and data entry are possible through the screen keyboard, a stylus, or external peripherals (Joseph, Corbeil, \& Valdes-Corbeil, 2007).

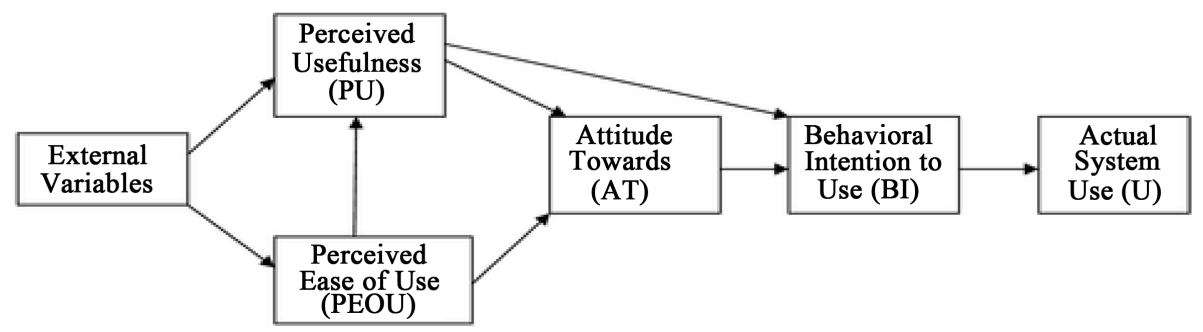

Figure 1. Description of the original TAM (Technology Acceptance Model) by Davis (1989).

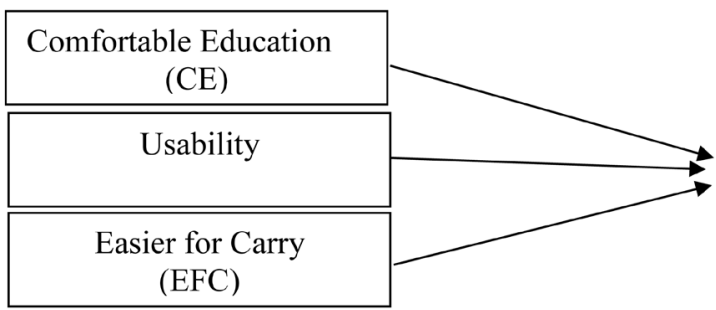

\begin{tabular}{|c|}
\hline $\begin{array}{c}\text { Discipline of students } \\
\text { (DOS) }\end{array}$ \\
\hline \hline $\begin{array}{c}\text { Academic achievement } \\
\text { (AA) }\end{array}$ \\
\hline
\end{tabular}

Figure 2. Shows the conceptual model used in this study. 


\section{Research Methodology}

This study was designed as a descriptive study, and focuses on research to answer research questions by comparing the academic performance of students before and after the use of the mobile learning system and virtual classroom, as well as the regularity of the students' school attendance before and after this system. The study sample consisted of 41 students girls and 39 students boys in the sixth grade. All of them were 12 years old in national school of "Paya Bunga" in Malaysia who has been studying their academic achievement before and after the adoption virtual classrooms and mobile learning system and investigation of students attending the school before and after the system studied.

In this study, the researcher collected students' academic results before the application of mobile learning system and virtual classrooms and after application and compared them to determine the impact of the new system on the students' achievement and analyse students' academic results of the students after the application of the new system. The results and recommendations of the study follow in the next sections.

\section{Analysis Procedures}

The researcher, in order to reach the objective results, has focused on student academic achievement before the application of mobile learning and virtual classrooms and student achievement after the application of the system and information on students' attendance. There are three main points as follows:

$\checkmark$ The researcher collected documents that prove student achievement after the application of mobile learning system and virtual classroom, which represents a sample study. The documents prepared by the school to documenting student achievement before and after the application of the mobile system and the research analyzed the data which are in the document only.

$\checkmark$ The researcher held a personal interview with the director of the school studied and obtained documents prove student achievement before the application of mobile learning system and virtual classrooms.

$\checkmark$ Researcher studied the statistics of students before and after the application of mobile learning system and virtual classroom. The researcher gets the documents from discipline unit in the school. The attendance evidence proves the discipline factor.

\section{Discussion and Conclusion}

After comparing the general situation of the students academically and behaviourally, the results show that students' achievement after the application of mobile learning and virtual classrooms has increased the academic level of the school (the study sample) and the ranking of the school increased on the national level according to Table 1 in 2009. Before the application of mobile learning and virtual classroom the school ranking was 4173 of 7617, but after the application of this system in 2011 the school ranking went up to 749 of 7674.

The raising school rank at the national level, as shown in Table 1 is a result of the commitment of the students to come to school and sit for lessons and tests that had a clear impact on the educational level, from the standpoint of the researcher the implementation of m-learning and virtual classroom in this school, its impact is evident in changing learning students' behaviour. Figure 3 shows the percentages of students attend the school has increased significantly and the table shows a comparison between the ratio of students attending school over the full year in 2010 and 2011 (a year in which the m-learning and virtual classrooms were not used) and the year after the implementation of e-learning and virtual classrooms.

Table 2 shows the change appears in the academic side of students between 2010 and 2011 after the implementation of m-learning. A clear rise in the academic achievement of students and the table shows a comparison

Table 1. School (study sample) ranking.

\begin{tabular}{|c|c|c|c|c|c|}
\hline YEAR & BAND & GPS & SKPM & COMPOSITE & RANK \\
\hline 2009 & - & 2.41 & 69.6 & 67.78 & $4173 / 7617$ \\
\hline 2010 & 3 & 1.69 & 77.6 & 74.91 & 2004/7617 \\
\hline 2011 & 2 & 2.06 & 88.5 & 81.25 & 749/7674 \\
\hline 2012 & 2 & 1.58 & 89.5 & 82.51 & Not Known \\
\hline
\end{tabular}




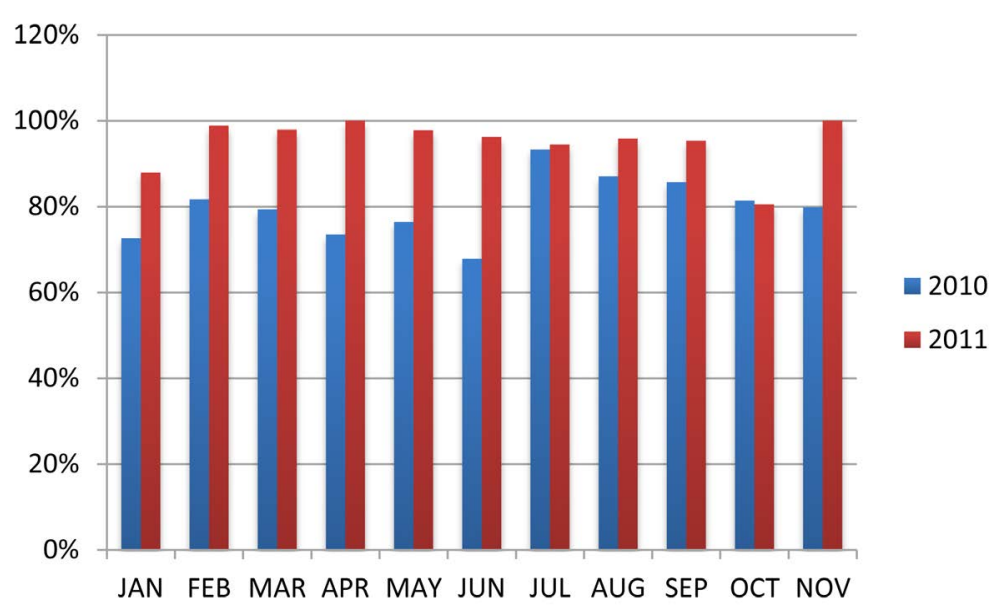

Figure 3. Students' monthly attendance rate 2010 and 2011.

Table 2. The changes in the students' academic performance between 2010 and 2011.

\begin{tabular}{|c|c|c|c|c|c|c|c|c|c|c|c|c|c|c|c|c|c|c|c|c|c|}
\hline \multirow[b]{2}{*}{ CANDIDATES } & \multirow[b]{2}{*}{$5 \mathrm{~A}$} & \multicolumn{3}{|c|}{$4 \mathrm{~A}$} & \multicolumn{2}{|l|}{$3 \mathrm{~A}$} & \multicolumn{3}{|c|}{$2 \mathrm{~A}$} & \multicolumn{5}{|c|}{$1 \mathrm{~A}$} & \multirow[b]{2}{*}{$5 \mathrm{~B}$} & \multirow{2}{*}{$\begin{array}{l}4 \mathrm{~B} \\
1 \mathrm{C}\end{array}$} & \multirow{2}{*}{$\begin{array}{l}3 \mathrm{~B} \\
2 \mathrm{C}\end{array}$} & \multirow{2}{*}{$\begin{array}{l}2 B \\
3 \mathrm{C}\end{array}$} & \multirow{2}{*}{${ }_{4 \mathrm{C}}^{1 \mathrm{~B}} 5 \mathrm{C}$} & \multicolumn{2}{|c|}{ MIN C } \\
\hline & & 1B & $1 \mathrm{C}$ & $2 B$ & $\begin{array}{l}1 \mathrm{~B} \\
1 \mathrm{C}\end{array}$ & $2 \mathrm{C}$ & 3B & $\begin{array}{l}2 \mathrm{~B} \\
1 \mathrm{C}\end{array}$ & $\begin{array}{l}1 \mathrm{~B} \\
2 \mathrm{C}\end{array} \quad 3 \mathrm{C}$ & 4B & $\begin{array}{l}3 \mathrm{~B} \\
1 \mathrm{C}\end{array}$ & $\begin{array}{l}2 \mathrm{~B} \\
2 \mathrm{C}\end{array}$ & $\begin{array}{l}1 \mathrm{~B} \\
3 \mathrm{C}\end{array}$ & $4 \mathrm{C}$ & & & & & & FRE & $\%$ \\
\hline TOV 1117 & & & & & & & & & & & 1 & & 1 & & & & & 2 & 2 & 6 & 35.2 \\
\hline TOV 1210 & & & & & & & 1 & 1 & & & 1 & & & & & & & & 1 & 4 & 40.00 \\
\hline OT 11117 & & 1 & & 1 & & & 2 & 1 & & 1 & & & & & 1 & & & 2 & 2 & 11 & 64.7 \\
\hline OT 11210 & & 1 & & & & & 1 & & & 1 & 1 & & & & & 1 & 1 & 1 & 2 & 9 & 90.00 \\
\hline OT 211 & 2 & 3 & 1 & & & & & & & 1 & 1 & & & & & 1 & & 1 & & 12 & 70.59 \\
\hline 10OT 212 & 2 & & & & & & 2 & & & 1 & & & & & & 3 & 1 & & 1 & 10 & 100 \\
\hline OT 31117 & & 1 & & & & & 5 & & & & & & & & & & 1 & 3 & 1 & 11 & 64.7 \\
\hline OT 31210 & 1 & 2 & & & & & 1 & & & 2 & & & & & 2 & 1 & & 1 & & 10 & 100 \\
\hline OT 41117 & 3 & 3 & & 1 & & & & & & & 1 & & & & & 1 & 2 & & & 11 & 64.7 \\
\hline OT 41210 & 1 & 2 & & & & & 2 & & & 1 & & & & & 2 & & 2 & & & 10 & 100 \\
\hline UPSR 2011 & & 2 & & 2 & & 1 & 2 & & & & 2 & 1 & & & & 2 & 1 & & 1 & 14 & 82.35 \\
\hline UPSR 2012 & 2 & 1 & & 2 & & & 3 & & & & & & & & & & 1 & 1 & & 10 & 100 \\
\hline
\end{tabular}

between the results of students in Take Off Value (TOV) and Operational Target Increment (OTI) tests before applying the new system and after application. The researcher has noted the clear changes in student achievement to the education system, as it is the only variable (the independent variable) in students learning.

This study tested student acceptance of m-learning technology using e-books and a virtual classroom as an effective model to understand the behaviour of students using the program Kelas Maya. The results have shown that ease of use and fun is important in determining the attitude towards the use. Students attending school before and after application of m-learning and virtual classroom showed that the student had high level of acceptance of this education style. This result is supported by other studies such as Liu et al. (2009) and Shroff, Deneen, \& Ng (Shroff, Deneen, \& Ng, 2011; Yunus, Nordin, Salehi, Embi, \& Salehi, 2013) who found that students favoured the use of high-level e-learning technology. In addition, the study revealed that perceived fun and perceived ease of use significantly affected attitudes toward use of e-books. This is supported by other studies such as Teo (2009) as well as Kiraz \& Ozdemir (Shroff et al., 2011; Yunus et al., 2013). The main purpose of this study is to discover the impact of e-learning and virtual classrooms on students' academic achievement and rate their commitment to come to the school. It also examines the relationship between the academic achieve- 
ment of students and e-learning technology as a modern and fun study method. The results of this study have shown that perceived fun and perceived ease of use have a significant effect on students' educational achievements. In other words, when students learn in school via e-books and virtual classrooms, their school attendance allows for increased academic achievement, showing a good effect for m-learning and virtual classrooms. These findings support the Teo \& van Schaik (2012), Teo (2009) Omar, Embi, \& Yunus ( 2012) studies. At the end of this study, the researcher found that the m-learning system and virtual classrooms have a clear positive impact on students' learning and their commitment to come to the school. This has an effect on the achievements of students in terms of their attendance. The researcher also believes that this study demonstrates the possibilities of the implementation of this educational system in all schools.

\section{References}

Al-Khalifa, H. (2006). Google Service for Education Geology and Research. Al-Riyadh Newspaper. http://www.alriyadh.com/139465

Argyris, C., \& Schön, D. A. (1996). Organizational Learning II. Theory Method and Practice.

Davis, F. D. (1985). A Technology Acceptance Model for Empirically Testing New End-User Information Systems: Theory and Results. Management, Ph.D., 291.

Dietzel, G. (2002). The Benefits of eBooks Learning with an Attitude. http://www.teachers.net/gazette/MAY02/dietzel.html

Ernst, E., Ostermann, K., \& Cook, W. (2006). A Virtual Class Calculus. ACM SIGPLAN Notices, 41, 270-282. http://dx.doi.org/10.1145/1111320.1111062

Fishbein, M., \& Ajzen, I. (1975). Belief, Attitude, Intention, and Behavior: An Introduction to Theory and Research. Canada: Addison-Wesley Publishing Company.

Henderson, S., \& Yeow, J. (2012). iPad in Education: A Case Study of iPad Adoption and Use in a Primary School (pp. 78-87). 2012 45th Hawaii International Conference on System Sciences. http://dx.doi.org/10.1109/HICSS.2012.390

Illich, I. (1970). Deschooling Society. Deschooling Society, 56-57.

Joseph, B., Corbeil, R., \& Valdes-Corbeil, M. E. (2007). Mobile Learning? Are You Ready for. Word Journal of the International Linguistic Association, 51-58.

Liu, S. H., Liao, H. L., \& Pratt, J. A. (2009). Impact of Media Richness and Flow on E-Learning Technology Acceptance. Computers and Education, 52, 599-607. http://dx.doi.org/10.1016/j.compedu.2008.11.002

Nordin, N. M., Hamzah, M. I., Yunus, M. M., \& Embi, M. A. (2010). The Mobile Learning Environment for the In-Service School Administrators. Procedia-Social and Behavioral Sciences, 7, 671-679. http://dx.doi.org/10.1016/j.sbspro.2010.10.091

Omar, H., Embi, M. A., \& Yunus, M. M. (2012). Learners' Use of Communication Strategies in an Online Discussion via Facebook. Procedia-Social and Behavioral Sciences, 64, 535-544. http://dx.doi.org/10.1016/j.sbspro.2012.11.063

Shroff, R. H., Deneen, C. C., \& Ng, E. M. W. (2011). Analysis of the Technology Acceptance Model in Examining Students' Behavioural Intention to Use an e-portfolio System. Australasian Journal of Educational Technology, 27, 600-618.

Teo, T. (2009). Modelling Technology Acceptance in Education: A Study of Pre-Service Teachers. Computers \& Education, 52, 302-312. http://dx.doi.org/10.1016/j.compedu.2008.08.006

Teo, T., \& van Schaik, P. (2012). Understanding the Intention to Use Technology by Preservice Teachers: An Empirical Test of Competing Theoretical Models. International Journal of Human-Computer Interaction, 28, 178-188. http://dx.doi.org/10.1080/10447318.2011.581892

Tiedeman, D. V., \& Knowles, M. (1979). The Adult Learner: A Neglected Species. Educational Researcher, 8, 20-22. http://dx.doi.org/10.2307/1174362

Trayek, F. A. A., Sariah, S., \& Hassan, S. (2013). Attitude towards the Use of Learning Management System among University Students: A Case Study. Turkish Online Journal of Distance Education, 14, 91-103.

West, T., \& Paine, C. (2012). The Opportunities of Mobile Learning for Executive Education. 360 — The Ashridge Journal.

Wylie, C. (2009). Getting More from School Self-Management. In J. Langley (Ed.), Tomorrow’s Schools 20 Years on... (pp. 135-146). Auckland: Cognition Institute.

Yunus, M. M., Nordin, N., Salehi, H., Embi, M. A., \& Salehi, Z. (2013). The Use of Information and Communication Technology (ICT) in Teaching ESL Writing Skills. English Language Teaching, 6, 1-8. http://dx.doi.org/10.5539/elt.v6n7p1 